\title{
Sistem Informasi Manajemen Logistik dan Peralatan Studi Kasus: BPBD Kabupaten Wonogiri
}

\author{
Anisa Pamiliawati ${ }^{\star}$, Nanang Maulana Y, Ovide Decroly Wisnu Ardhi, Sahirul Alim Tri Bawono, Muhammad \\ Asri Safi'ie
}

Fakultas MIPA, Program Studi D3 Teknik Informatika, Universitas Sebelas Maret

Email: anisa_pamiliawati@student.uns.ac.id* ${ }^{\star}$,nanang.my@staff.ac.id, ovide@staff.uns.ac.id, sahirul@staff.uns.ac.id, safiie99@mipa.uns.ac.id

\begin{tabular}{l} 
Info Artikel \\
\hline Kata Kunci : \\
logistik, peralatan, logistik \\
kemanusiaan, sistem informasi, \\
fair share allocation \\
Keywords : \\
logistics, equipment, \\
humanitarian logistics, \\
information system, fair share \\
allocation \\
\\
Tanggal Artikel \\
Dikirim : 20 November 2019 \\
Direvisi : 27 November 2019 \\
Diterima : 30 November 2019
\end{tabular}

\begin{abstract}
Abstrak
Hampir semua kecamatan di Kabupaten Wonogiri memiliki potensi kerawanan bencana alam mulai dari tanah longsor, kebakaran, banjir, angin puting beliung, tanah bergerak, tanah ambles, dan kekeringan. Kerugian yang ditimbulkan dari bencana tersebut berupa rumah rusak dan korban jiwa. Manajemen gudang bertujuan untuk menjamin ketersediaan dukungan logistik dan peralatan setiap waktu. Sistem informasi dibuat untuk memantau tanggal kedaluwarsa, menghitung alokasi bantuan, dan dokumentasi pergerakan barang untuk menghitung stok. Logistik permakanan rawan kedaluwarsa, sehingga harus dipantau agar dalam kondisi yang baik untuk dijadikan bantuan. Menghitung alokasi bantuan dilakukan untuk mengetahui jumlah hari yang dibutuhkan untuk melakukan penyesuaian pendistribusian selanjutnya. Perhitungan alokasi menggunakan metode fair share allocation. Hasil yang dicapai adalah mengelola data kategori, data sumber, data kecamatan, data kelurahan, data bencana, data barang, data inventarisasi, data kedaluwarsa, data penyimpanan, data detail masuk, data tidak layak, data posko, data hitung, data pengeluaran, data detail keluar, dan data peminjaman.
\end{abstract}

\begin{abstract}
Abstarct
Almost all sub-districts in Wonogiri Regency have the potential to be vulnerable to natural disasters ranging from landslides, fires, floods, whirlwinds, moving land, sinking land, and drought. Losses arising from the disaster in the form of damaged homes and fatalities. Warehouse management aims to ensure the availability of logistical support and equipment at all times. An information system is created to monitor expiration dates, calculate aid allocations, and document movement of goods to calculate stock. Food logistics is prone to expiration, so it must be monitored so that it is in good condition for assistance. Calculating the allocation of aid is done to find out the number of days needed to make further distribution adjustments. The allocation calculation uses the fair share allocation method. The results achieved are managing category data, source of procurement data, sub-district data, village data, disaster data, item data, inventory data, expired data, incoming goods data, detail data of incoming goods, improper goods data, post data, calculated data, outgoing goods data, detail data of outgoing goods, and borrowing data.
\end{abstract}




\section{PENDAHULUAN}

Hampir semua kecamatan di Kabupaten Wonogiri memiliki potensi kerawanan bencana alam mulai dari tanah longsor, kebakaran, banjir, angin puting beliung, tanah bergerak, tanah ambles, dan kekeringan. Kerugian yang ditimbulkan dari bencana tersebut berupa rumah rusak dan korban jiwa. Warga yang terkena dampak dari bencana membutuhkan bantuan yang tepat dan cepat. Bantuan yang dibutuhkan meliputi sandang, pangan, papan, dan peralatan untuk menunjang pelaksanaan penaggulangan bencana.

Karakteristik bencana alam yang terjadi secara tiba-tiba perlu diantisipasi melalui manajemen gudang. Manajemen gudang bertujuan untuk menjamin ketersediaan dukungan logistik dan peralatan setiap waktu. Bidang atau seksi kedaruratan dan logistik bertanggung jawab atas manajemen gudang BPBD (Badan Penanggulangan Bencana Daerah) Kabupaten Wonogiri. Tugas yang dilakukan dalam memanajemen gudang adalah menjamin kualitas logistik dan peralatan, sehingga saat terjadi bencana logistik dan peralatan yang didistribusikan dalam kondisi yang baik. Sehingga diperlukan sistem manajemen gudang yang mampu mengelola data gudang melalui pembuatan sistem informasi manajemen logistik dan peralatan. Sistem informasi dibuat untuk memantau tanggal kedaluwarsa, menghitung alokasi bantuan, dan dokumentasi pergerakan barang untuk menghitung stok.

Penelitian sebelumnya [1] menyatakan pembuatan Sistem Informasi Warehouse Bantuan Logistik Korban Bencana Alam Berbasis Web dengan Framework Codeigniter 3.0 bertujuan untuk membuat sistem informasi mengenai penyaluran bantuan logistik kepada korban bencana. Sistem ini melibatkan tiga aktor yaitu superadmin, admin posko bantuan, dan admin posko pengungsi. Input yang dibutuhkan untuk menjalankan sistem adalah data barang, data posko bantuan, data posko pengungsi, data penerimaan barang bantuan, data permintaan barang bantuan, data user posko bantuan, dan data user posko pengungsi. Data yang telah diinputkan selanjutnya diproses untuk menghasilkan output berupa laporan data permintaan, data penerimaan, data pengiriman, data stok barang, dan dapat memverifikasi barang yang telah diterima.

Penelitian kedua [2] menyatakan Sistem Informasi E-Logistik dapat melakukan manajemen proses produksi, pengiriman barang jadi, permintaan bahan baku, dan penerimaan bahan. Proses yang terjadi pada sistem informasi e-logistik adalah pihak produksi membuat jumlah bahan baku yang dibutuhkan untuk memproduksi satu unik barang dan target produksi harian. Pihak gudang akan menghitung barang yang harus dikeluarkan dari gudang untuk melakukan produksi sesuai data yang telah diinput oleh pihak produksi. Apabila barang yang ada di gudang mencapai minimum stok maka pihak gudang dapat melakukan permintaan barang berdasarkan minimum stok dan hasil perhitungan EOQ (Economic Order Quantity).

Penelitian ketiga [3] menyatakan Sistem Informasi Logistik (SIMLOG) dapat melakukan manajemen stok barang, barang masuk, barang keluar dan peramalan. Peramalan digunakan untuk analisis kebutuhan dan distribusi. Metode yang digunakan dalam peramalan adalan EOQ yang hasilnya untuk menentukan reorder point. Penelitian keempat [4] mengenai Tinjauan Sistem Prosedur Pengeluaran Material C212 di Gudang Manajemen Persediaan PT. X. Prosedur pengeluaran dalam pergerakan material menjadi sumber informasi terhadap proses pengadaan suatu material. Dengan keakuratan data pengeluaran, dapat mengetahui jumlah barang yang masih atau habis di gudang. Hal yang harus diperhatikan dalam manajemen persediaan adalah waktu kedatangan barang yang akan dipesan kembali, kuanitas jumlah barang yang akan disimpan, dan safety stock. Enam jenis aktivitas pergerakan material yaitu receiving voucher, transfer of material, material ticket, return to store, material delivery / packing list, dan proforma invoice.

Penelitian kelima [5] mengenai Pembuatan Aplikasi Terintegrasi, Pendataan Barang di Gudang Berbasis Android. Aplikasi ini dibuat agar di gudang dapat melakukan crosscheck terhadap pengiriman yang akan dilakukan sehingga pihak checker di gudang dapat melakukan pemeriksaan secara cepat dengan mengacu pada basisdata yang ada pada perusahaan. Fungsionalitas aplikasi dapat memasukkan data barang masuk, data barang keluar, melihat laporan persediaan, dan memasukkan data pemeriksaan.

Penelitian keenam [6] terkait Rancang Bangun Sistem Informasi Bantuan Logistik Bencana Studi Kasus pada BPBD Kabupaten Magelang. Fokus pembuatan sistem informasi untuk menangani pada fase perencanaan dan fase penerimaan bantuan kategori logistik. Sistem informasi ini menangani manajemen logistik bantuan bencana seperti mengelola data kebutuhan dasar, logistik masuk, dan logistik keluar.

Perbedaan aplikasi di atas dengan sistem informasi manajemen logistik dan peralatan adalah dapat mengetahui barang yang sudah mendekati kedaluwarsa, perhitungan stok dan pemilihan metode perhitungan. Perhitungan stok dipengaruhi oleh barang yang disimpan di gudang, barang yang dikeluarkan dari gudang, dan barang yang tidak layak dijadikan bantuan. Penyimpanan di gudang dapat terganggu oleh faktor eksternal sehingga menimbulkan kerusakan barang. Kerusakan barang menyebabkan barang tidak layak dijadikan bantuan. Perhitungan alokasi pendistribusian menggunakan metode fair share allocation untuk menentukan jumlah hari dan jumlah alokasi. 
Metode fair share allocation digunakan untuk menghitung distribusi barang ke berbagai lokasi. Saat terjadi bencana, BPBD akan mendirikan sejumlah posko sesuai daerah yang terkena dampak, sehingga perhitungan alokasi pendistribusian menggunakan fair share allocation. Fokus utama sistem informasi untuk memanajemen logistik dan peralatan di gudang BPBD Kabupaten Wonogiri. Hasil yang diharapkan adalah dapat membuat sistem informasi manajemen logistik di BPDB Kabupaten Wonogiri untuk membantu petugas gudang BPBD Kabupaten Wonogiri dalam mengelola logistik dan peralatan.

\section{METODE PENELITIAN}

Pembuatan sistem informasi menggunakan metode waterfall, terdiri dari tiga tahap yaitu pengumpulan data, rancangan sistem, dan pengujian.

\subsection{Pengumpulan data}

Mengumpulkan data yang dibutuhkan melalui wawancara dan studi pustaka. Wawancara dilakukan dengan mencari informasi melalui narasumber yang ada di BPBD Wonogiri. Studi pustaka dilakukan untuk mengetahui penelitian sebelumnya yang terkait dengan bantuan logistik bencana alam.

\subsection{Rancangan Sistem}

Hasil dari pengumpulan data digunakan untuk mendesain sistem meliputi rancangan sistem, rancangan database, dan desain antarmuka. Implementasi dilakukan dengan membuat sistem ke dalam kode pemrograman sesuai dengan rancangan yang telah dianalisis dan didesain sebelumnya.

\subsection{Pengujian}

Setelah tahap implementasi selesai dilakukan, tahap selanjutnya adalah melakukan pengujian. Pengujian dilakukan untuk mengetahui apakah sistem yang telah dibuat dapat berjalan dengan baik.

\section{HASIL DAN PEMBAHASAN}

\subsection{Fair Share Allocation}

Perhitungan untuk menentukan hari yang dibutuhkan untuk menyediakan barang yang akan datang [7] dengan rumus (1):

$$
\mathrm{DS}=\frac{A Q+\sum_{i=1}^{n} \mathrm{I}_{j}}{\sum_{i=1}^{n} \mathrm{D}_{j}}
$$

Catatan:

DS = hari penyediaan barang untuk stok gudang

$A Q=$ stok yang dialokasikan oleh gudang pabrik

$\mathrm{lj}=$ stok untuk gudang $\mathrm{j}$

$D j=$ permintaan harian untuk gudang $j$

Jumlah yang dialokasikan untuk setiap gudang ditentukan dengan rumus (2):

$$
A_{j}=\left(D S-\frac{I_{j}}{D_{j}}\right) \times D_{j}
$$

Catatan:

$\mathrm{Aj}=$ jumlah alokasi gudang $\mathrm{j}$

DS = hari yang dibutuhkan untuk penyediaan barang oleh setiap gudang

$\mathrm{lj}=$ stok gudang $\mathrm{j}$

$\mathrm{Dj}=$ permintaan harian gudang $\mathrm{j}$

Hari penyediaan barang yang akan datang adalah perkiraan kapan dilakukan penyediaan barang selanjutnya berdasakan jumlah barang yang dialokasikan dari gudang pabrik, stok gudang, dan permintaan harian gudang. Apabila rumus tersebut diterapkan pada sistem maka gudang BPBD berperan seperti gudang pabrik dan posko 
berperan seperti gudang. Data yang dibutuhkan untuk menentukan hari untuk menyediakan barang adalah jumlah barang yang dialokasikan dari gudang BPBD, stok posko j, permintaan harian posko j. Data yang dibutuhkan untuk menentukan jumlah alokasi untuk setiap posko adalah hari untuk menyediakan barang, stok posko j, dan permintaan harian posko j. Hari untuk menyediakan barang berasal dari hasil perhitungan rumus (1). Sebelum menentukan jumlah alokasi setiap posko maka harus mengetahui hari untuk menyediakan barang yang akan datang.

\subsection{Proses Bisnis}

Admin dapat melakukan tugas yang dilakukan oleh Petugas. Admin memasukkan data kategori, sumber, kecamatan, kelurahan, dan bencana. Petugas memasukkan data barang, kedaluwarsa, dan inventarisasi. Input data kedaluwarsa akan menghasilkan flash message barang kedaluwarsa. Petugas menerima dan menyimpan barang di gudang kemudian memasukkan data penyimpanan dan detail masuk. Hasil dari data penyimpanan dan detail masuk yang dimasukkan adalah bukti penyimpanan. Petugas melakukan pemeriksaan berkala atau stock opname, apabila menemukan barang dengan kondisi tidak layak untuk diberikan sebagai bantuan maka Petugas memasukkan data tidak layak. Validasi dilakukan setelah menindaklanjuti barang tidak layak tersebut. Apabila terjadi bencana, petugas memasukkan data hitung pengalokasian untuk membantu dalam pengambilan keputuasan sebelum melakukan distribusi. Admin memasukkan data posko. Setelah data posko tersedia Petugas dapat memasukkan data pengeluaran barang dari gudang yang terdiri dari data pengeluaran dan detail keluar. Hasil dari data penyimpanan dan detail keluar yang dimasukkan adalah bukti pengeluaran. Petugas memvalidasi pengiriman apabila barang sudah sampai di posko tujuan. Barang yang dikeluarkan dari gudang dengan kondisi pinjam pakai akan divalidasi oleh Petugas apabila barang sudah dikembalikan. Data yang telah dimasukkan akan menghasilkan laporan dan kartu barang. Proses bisnis diilustrasikan seperti Gambar 3.1 Proses Bisnis

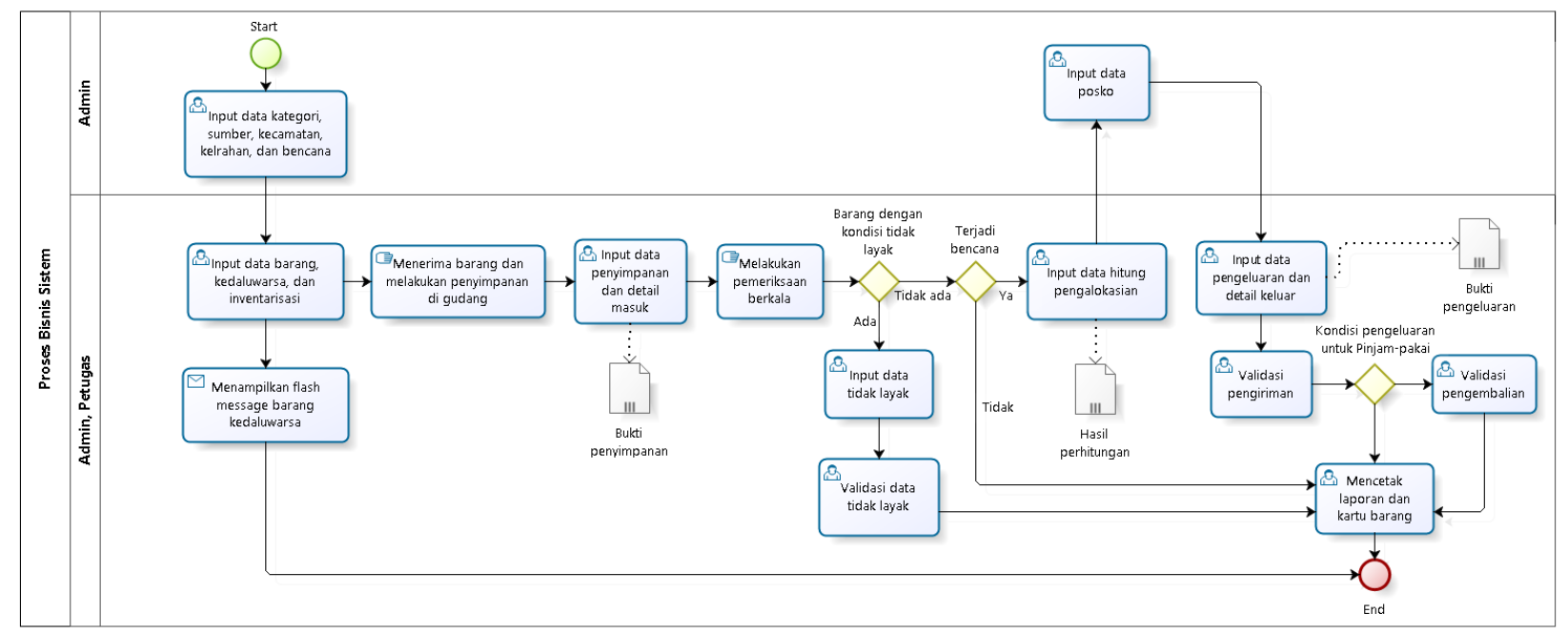

Gambar 3. 1 Proses Bisnis

\subsection{Kebutuhan Fungsional}

Kebutuhan fungsional berfungsi untuk menjelaskan layanan - layanan yang disediakan oleh sistem untuk digunakan oleh pengguna. Kebutuhan fungsional sistem seperti ditunjukkan pada tabel 3. 1 Tabel Kebutuhan Fungsional.

Tabel 3. 1 Tabel Kebutuhan Fungsional.

\begin{tabular}{lll}
\hline No & Deskripsi & Aktor \\
\hline FR 1 & Mengelola data kategori & Admin \\
\hline FR 2 & Mengelola data sumber & Admin \\
\hline FR 3 & Mengelola data kecamatan & Admin \\
\hline FR 4 & Mengelola data kelurahan & Admin \\
\hline FR 5 & Mengelola data bencana & Admin \\
\hline FR 6 & Mengelola data barang & Admin, Petugas \\
\hline
\end{tabular}




\begin{tabular}{lll}
\hline FR 7 & Mengelola data inventarisasi & Admin, Petugas \\
\hline FR 8 & Mengelola data kedaluwarsa & Admin, Petugas \\
\hline FR 9 & Mengelola data penyimpanan & Admin, Petugas \\
\hline FR 10 & Mengelola data detail masuk & Admin, Petugas \\
\hline FR 11 & Mengelola data tidak layak & Admin, Petugas \\
\hline FR 12 & Mengelola data hitung & Admin, Petugas \\
\hline FR 13 & Mengelola data posko & Admin \\
\hline FR 14 & Mengelola data pengeluaran & Admin, Petugas \\
\hline FR 15 & Mengelola data detail keluar & Admin, Petugas \\
\hline FR 16 & Mengelola data peminjaman & Admin, Petugas \\
\hline
\end{tabular}

\subsection{Relasi Antar Tabel}

Relasi Antar Tabel sistem ditunjukkan seperti Gambar 3. 2 Relasi Antar Tabel di atas. Relasi Antar Tabel digunakan untuk menggambarkan hubungan antar tabel pada database dengan desain fisik berupa tabel. Tabel barang merujuk pada tabel kategori. Tabel kedaluwarsa, tabel tidak layak, tabel inventarisasi, dan hitung merujuk pada tabel barang. Tabel detail masuk merujuk pada tabel penyimpanan dan tabel barang. Tabel penyimpanan merujuk pada tabel sumber. Tabel detail keluar merujuk pada tabel pengeluaran dan tabel barang. Tabel pengeluaran merujuk pada tabel posko. Tabel posko merujuk pada tabel kelurahan dan tabel bencana. Tabel kelurahan merujuk pada tabel kecamatan.

\subsection{ERD (Entity Relationship Diagram)}

Entity Relationship Diagram digunakan untuk menggambarkan hubungan antar tabel ke dalam diagram menggunakan notasi yang telah ditentukan. ERD sistem terdiri dari 15 tabel yaitu tabel kategori, sumber, kecamatan, kelurahan, bencana, barang, inventarisasi, kedaluwarsa, penyimpanan, detail masuk, tidak layak, hitung, posko, pengeluaran, detail keluar. Terdapat sembilan kardinalitas one to many, dua kardinalitas many to many, dan satu kardinalitas one to one. ERD sistem diilustrasikan seperti pada Gambar 3. 3 Entity Relationship Diagram.

\subsection{Implementasi}

\subsubsection{Halaman index}

\subsubsection{Halaman index data barang}

Halaman index data barang berfungsi untuk menampilkan gridview dari data barang. Gridview menampilkan data barang yang terdiri dari kode barang, nama barang, standar minimal, satuan, nama jenis, dan nama kategori. Terdapat tombol untuk menghubungkan dengan halaman form input data dan cetak kartu barang. Gambar halaman index data barang seperti pada Gambar 3. 4 Halaman index data barang. 


\begin{tabular}{|c|c|c|}
\hline \multicolumn{3}{|c|}{ hitung } \\
\hline kasi_tujuan 13 & Double & \\
\hline id hitung fsa & integer & $\leq p h x$ \\
\hline id_barang & integer & $<f o s$ \\
\hline jumlah_alokasi & integer & \\
\hline tujuan1 & $\begin{array}{l}\text { varchar(100) } \\
\text { integer }\end{array}$ & \\
\hline jumlah_stok1 & integer & \\
\hline $\begin{array}{l}\text { tujuan2 } \\
\text { jumlah_keb_harian2 }\end{array}$ & $\begin{array}{l}\text { varchar(100) } \\
\text { integer }\end{array}$ & \\
\hline & integer & \\
\hline tujuan3 3 & decimal $(100)$ & \\
\hline jumlah_keb_harian3 & integer & \\
\hline jumlah_stok3 & integer & \\
\hline $\begin{array}{l}\text { tujuan4 } 4 \\
\text { jummlah_keb_harian4 }\end{array}$ & $\begin{array}{l}\text { varchar(100) } \\
\text { integer }\end{array}$ & \\
\hline jumlah_stok4 & integer & \\
\hline tujuan 5 & varchar(100) & \\
\hline $\begin{array}{l}\text { jumlah_keb_harian5 } \\
\text { jumlah_stok5 }\end{array}$ & $\begin{array}{l}\text { integer } \\
\text { integer }\end{array}$ & \\
\hline tujuane & varchar $(100)$ & \\
\hline $\begin{array}{l}\text { jumlah_keb_harian6 } \\
\text { jumlah_stok6 }\end{array}$ & integer & \\
\hline $\begin{array}{l}\text { Jumlan_tono } \\
\text { tujuan } 7\end{array}$ & $\begin{array}{l}\text { integer } \\
\text { varchar(100) }\end{array}$ & \\
\hline jumlah_keb_harian7 7 & integer & \\
\hline jumlah_stok7 & integer & \\
\hline tujuan 8 & varchar $(100)$ & \\
\hline jumlah_keb_harian8 & integer & \\
\hline jumlah_stok8 & & \\
\hline $\begin{array}{l}\text { tujuan9 } \\
\text { jumlah_keb_harian9 }\end{array}$ & $\begin{array}{l}\text { varchar(100) } \\
\text { integer }\end{array}$ & \\
\hline jumlah_stok 9 & integer & \\
\hline tujuan 10 & varchar $(100)$ & \\
\hline jumlah_keb_harian 10 & integer & \\
\hline jumlah_stok10 & integer & \\
\hline $\begin{array}{l}\text { tujuann11 } \\
\text { jumlag keb harian11 }\end{array}$ & varchar $(100)$ & \\
\hline $\begin{array}{l}\text { jumlah_keb_harian11 } \\
\text { jumlah_stok11 }\end{array}$ & $\begin{array}{l}\text { integer } \\
\text { integer }\end{array}$ & \\
\hline tujuan 12 & varchar $(100)$ & \\
\hline jumlah_keb_harian 12 & integer & \\
\hline jumlah_stok12 & integer & \\
\hline tujuan 13 & varchar(100) & \\
\hline $\begin{array}{l}\text { jumlah_keb_harian13 } \\
\text { jumlah_stok13 }\end{array}$ & integer & \\
\hline $\begin{array}{l}\text { tujuan } 14 \\
\text { te }\end{array}$ & varchar $(100)$ & \\
\hline jumlah_keb_harian 14 & integer & \\
\hline jumlah_stok14 & integer & \\
\hline tujuan 15 & varchar $(100)$ & \\
\hline jumlah_keb_harian15 & integer & \\
\hline $\begin{array}{l}\text { jumlah_stok15 } \\
\text { tujuan16 }\end{array}$ & integer & \\
\hline $\begin{array}{l}\text { tujuann18 } \\
\text { jummlah_keb_harian } 16\end{array}$ & $\begin{array}{l}\text { varchargr(100) } \\
\text { integer }\end{array}$ & \\
\hline jumlah_stok16 & integer & \\
\hline tujuan 17 & varchar(100) & \\
\hline $\begin{array}{l}\text { jumlah_keb_harian17 } \\
\text { jumlah_stok17 }\end{array}$ & $\begin{array}{l}\text { integer } \\
\text { integer }\end{array}$ & \\
\hline $\begin{array}{l}\text { tujuan } 18 \\
\text { te }\end{array}$ & varchar $(100)$ & \\
\hline jumlah_keb_harian18 & integer & \\
\hline jumlah_stok18 & integer & \\
\hline tujuan19 & varchar $(100)$ & \\
\hline jumlah_keb_harian 19 & integer & \\
\hline jumlah_stok19 & integer & \\
\hline tujuan20 & varchar(100) & \\
\hline $\begin{array}{l}\text { jumlah_keb_harian20 } \\
\text { jumlah_stok20 }\end{array}$ & integer & \\
\hline $\begin{array}{l}\text { jumlah_stok20 } \\
\text { tujuan21 }\end{array}$ & $\begin{array}{l}\text { integer } \\
\text { varchar(100) }\end{array}$ & \\
\hline jumlah_keb_harian21 & integer & \\
\hline jumlah_stok21 & integer & \\
\hline tujuan 22 & varchar(100) & \\
\hline jumlah_keb_harian22 & integer & \\
\hline $\begin{array}{l}\text { jumlah_stok22 } \\
\text { tujusn23 }\end{array}$ & integer & \\
\hline $\begin{array}{l}\text { tujuan } 23 \\
\text { jumlah keb harian } 23\end{array}$ & varchar $[100)$ & \\
\hline jumlah_keb_hariann23 & integer & \\
\hline $\begin{array}{l}\text { jumlah_stok23 } \\
\text { tujuan24 }\end{array}$ & integer & \\
\hline $\begin{array}{l}\text { tujuan24 } \\
\text { jumlah_keb_harian24 }\end{array}$ & $\begin{array}{l}\text { varchar(100) } \\
\text { integer }\end{array}$ & \\
\hline jumlah_stok 24 & integer & \\
\hline tujuan 25 & varchar $(100)$ & \\
\hline jumlah_keb_harian25 & integer & \\
\hline jumlah_stok25 & integer & \\
\hline jumlah_hari & Double & \\
\hline alokasi_tujuan1 & Double & \\
\hline slokasi_tujuan2 & Double & \\
\hline alokasi_tujuan 3 & Double & \\
\hline slokasi_tujuan4 & Double & \\
\hline alokasi_tujuan5 & Double & \\
\hline slokasi_tujuan6 & Double & \\
\hline alokasi_tujuan 7 & Double & \\
\hline alokasi_tujuan8 & Double & \\
\hline slokasi_tujuan9 & Double & \\
\hline alokasi_tujuan 10 & Double & \\
\hline alokasi_tujuan11 & Double & \\
\hline alokasi_tujuan 12 & Double & \\
\hline slokasi_tujuan14 & Double & \\
\hline alokssi_tujuan 15 & Double & \\
\hline alokasi_tujuan 16 & Double & \\
\hline slokasi_tujuan17 & Double & \\
\hline alokasi_tujuan18 & Double & \\
\hline alokasi_tujuan 19 & Double & \\
\hline alokasi_tujuan20 & Double & \\
\hline alokasi_tujuan21 & Double & \\
\hline alokasi_tujuan 22 & Double & \\
\hline slokasi_tujuan 23 & Double & \\
\hline slokasi tujuan24 & Double & \\
\hline alokasi_tujuan25 & Double & \\
\hline
\end{tabular}

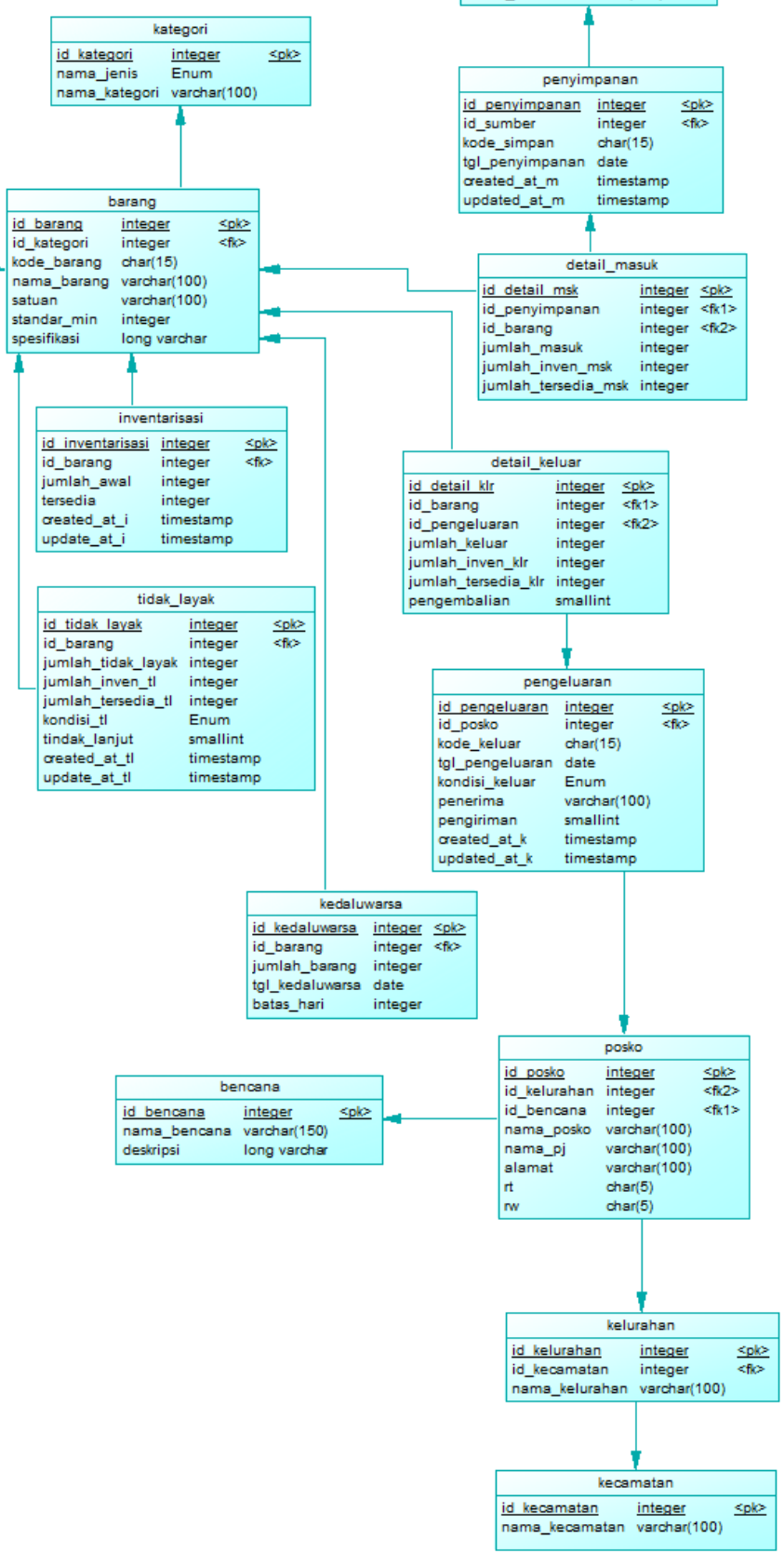

Gambar 3. 2 Relasi Antar Tabel 


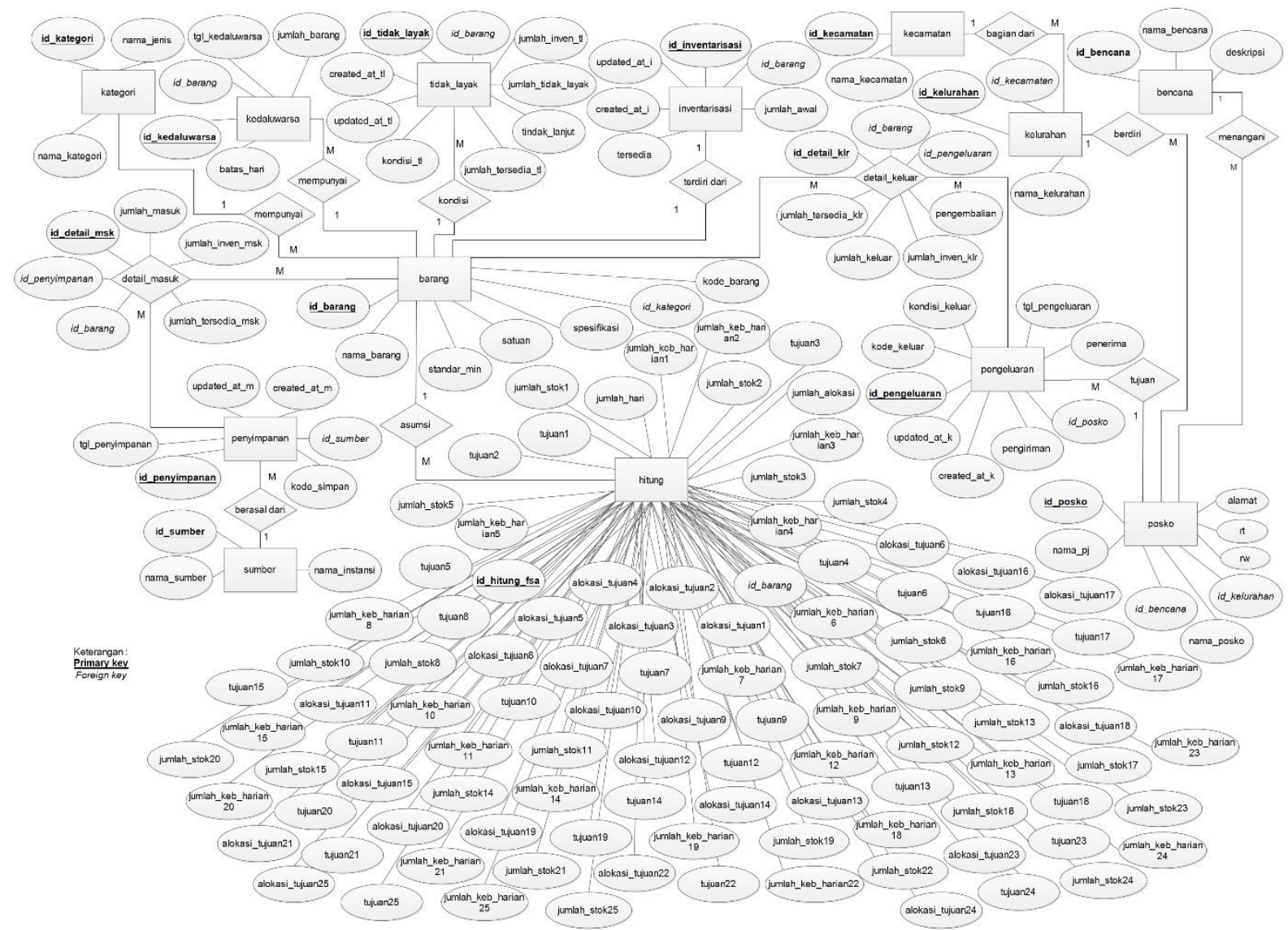

Gambar 3. 3 Entity Relationship Diagram

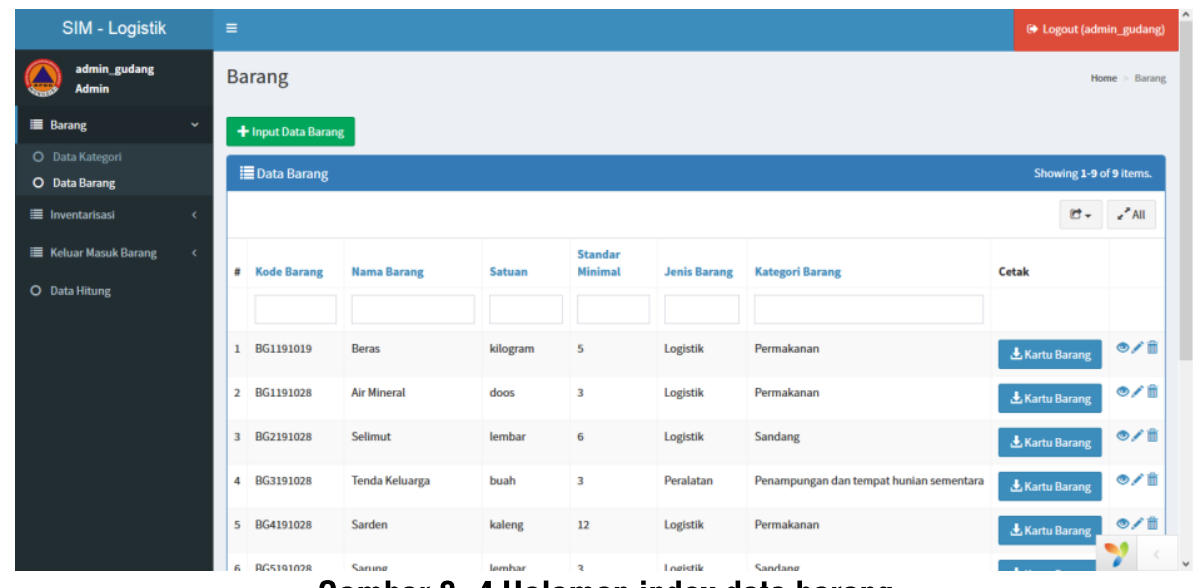

\section{Gambar 3. 4 Halaman index data barang}

\subsubsection{Halaman index data penyimpanan}

Halaman index data penyimpanan berfungsi untuk menampilkan gridview dari data penyimpanan. Gridview menampilkan data penyimpanan yang terdiri dari kode simpan, tanggal penyimpanan, nama sumber, dan nama instansi. Terdapat tombol untuk menghubungkan dengan halaman form input data, cetak rekap durasi, cetak rekap sumber, dan cetak bukti penyimpanan. Gambar halaman index data penyimpanan seperti pada Gambar 3. 5 Halaman index data penyimpanan. 


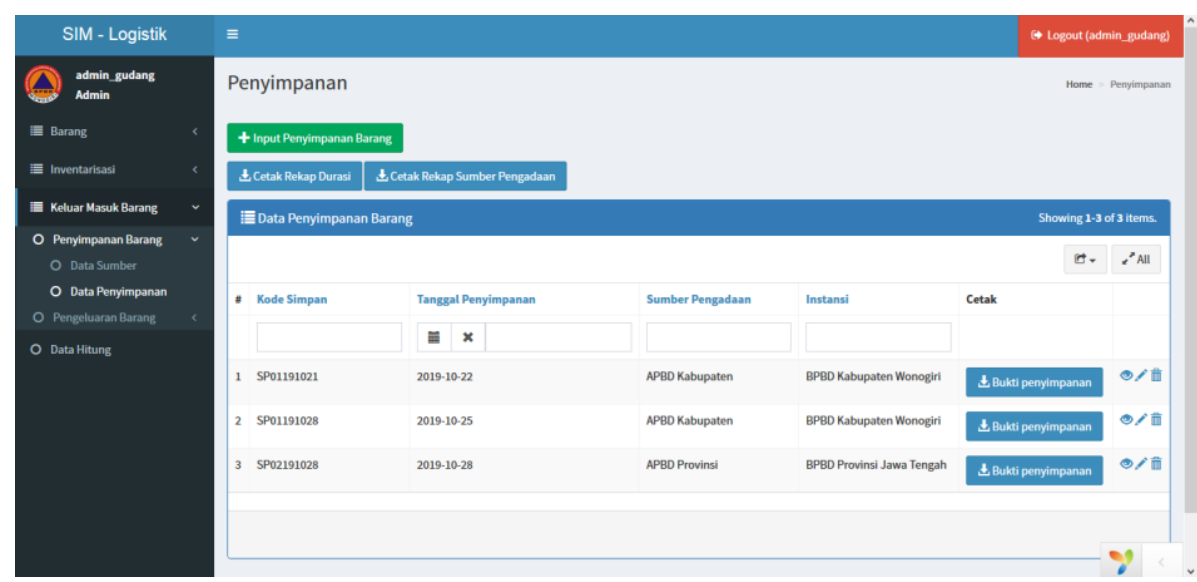

Gambar 3. 5 Halaman index data penyimpanan

\subsubsection{Halaman index data pengeluaran}

Halaman index data pengeluaran berfungsi untuk menampilkan gridview dari data pengeluaran. Gridview menampilkan data pengeluaran yang terdiri dari kode keluar, tanggal pengeluaran, kondisi keluar, dan penerima. Terdapat tombol untuk menghubungkan dengan halaman form input data, cetak rekap durasi, cetak rekap penerima, cetak bukti pengeluaran, dan validasi pengiriman. Gambar halaman index data pengeluaran seperti pada Gambar 3. 6 Halaman index data pengeluaran.

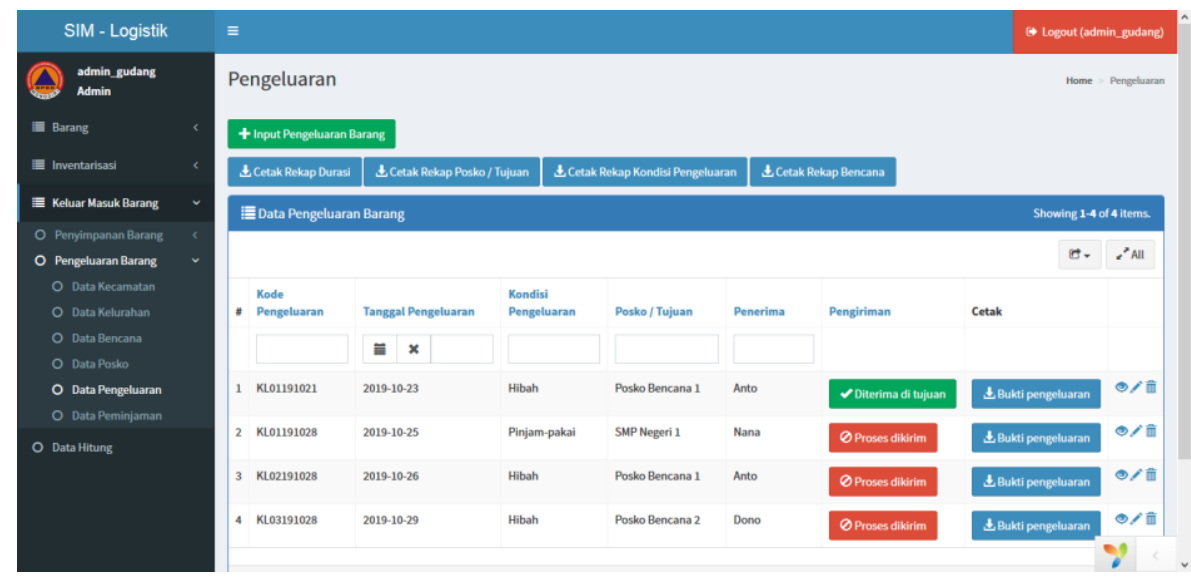

Gambar 3. 6 Halaman index data pengeluaran

\subsubsection{Halaman detail view}

\subsubsection{Halaman detail view penyimpanan}

Halaman view data penyimpanan berfungsi untuk menampilkan detail view dari data penyimpanan yang dipilih dan gridview data detail masuk. Detail view menampilkan data penyimpanan yang terdiri dari kode simpan, tanggal penyimpanan, nama sumber, nama instansi, dan tanggal dan waktu data disimpan ke database. Gridview menampilkan data detail masuk yang berelasi dengan data pengeluaran dan data barang yang terdiri dari kode simpan, kode barang, nama barang, jumlah awal, jumlah masuk, jumlah tersedia, dan satuan. Gambar halaman detail view data penyimpanan seperti pada Gambar 3. 7 Halaman detail view data penyimpanan. 

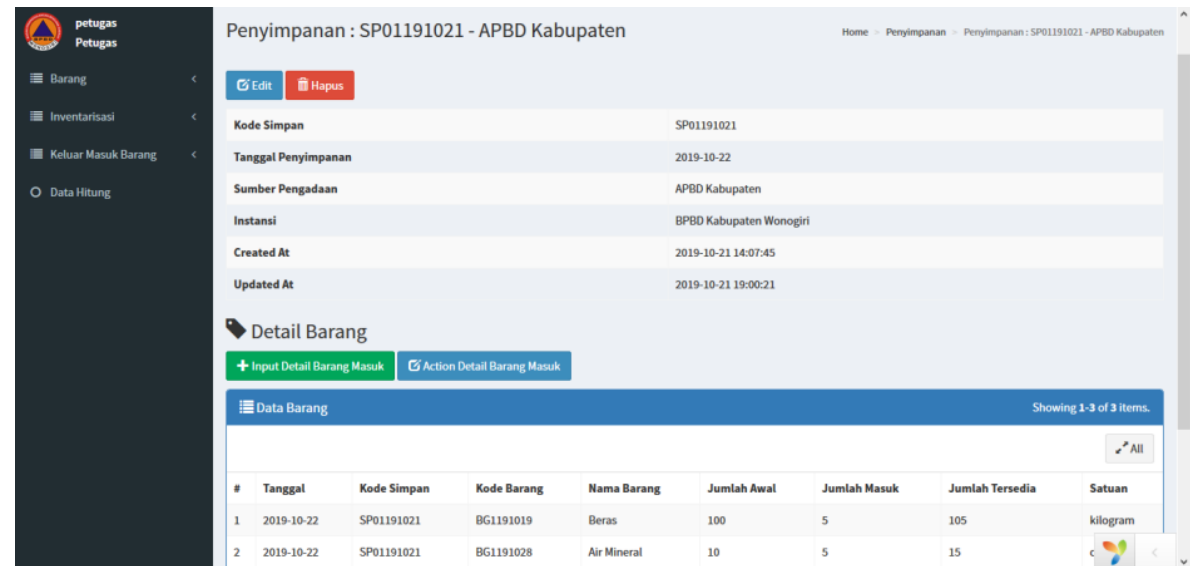

Gambar 3. 7 Halaman detail view data penyimpanan

\subsubsection{Halaman detail view pengeluaran}

Halaman view data pengeluaran berfungsi untuk menampilkan detail view dari data pengeluaran yang dipilih dan gridview data detail keluar. Detail view menampilkan data pengeluaran yang terdiri dari kode pengeluaran, tanggal pengeluaran, kondisi pengeluaran, pengiriman, penerima, posko / tujuan, alamat, RT, RW, kelurahan, kecamatan, penanggung jawab posko / tujuan dan tanggal dan waktu data disimpan ke database. Gridview menampilkan data detail keluar yang berelasi dengan data pengeluaran dan data barang yang terdiri dari kode keluar, kode barang, nama barang, jumlah awal, jumlah keluar, jumlah tersedia, dan satuan. Gambar halaman detail view data pengeluaran seperti pada Gambar 3. 8 Halaman detail view data pengeluaran.

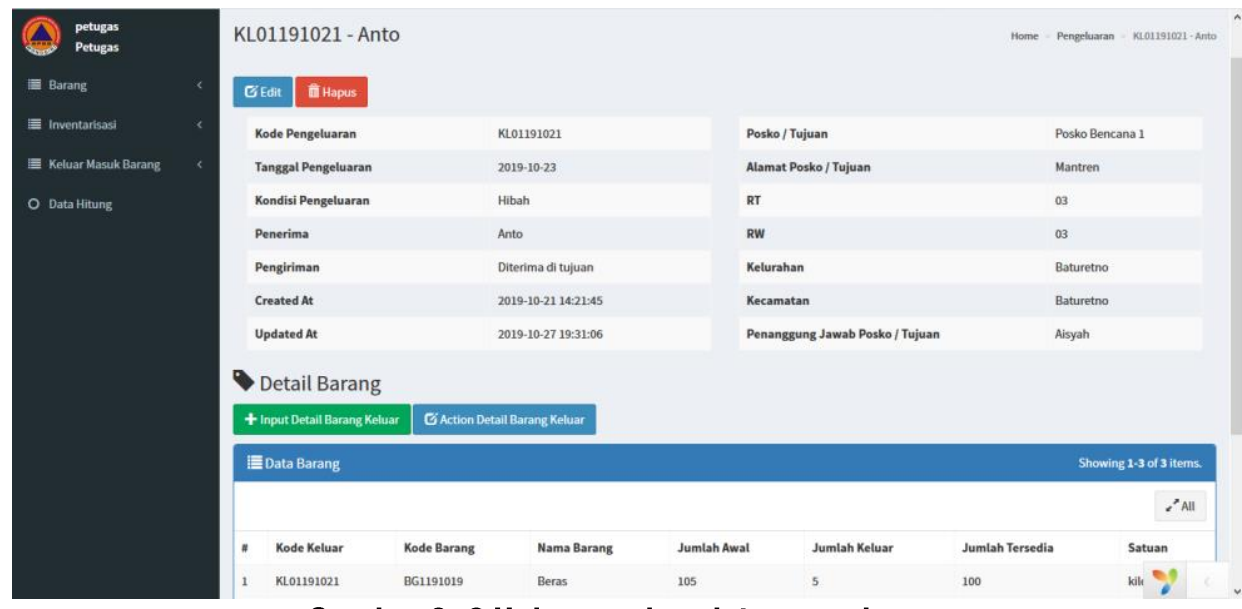

Gambar 3. 8 Halaman view data pengeluaran

\subsubsection{Halaman input}

\subsubsection{Halaman input data hitung pengalokasian}

Halaman input data hitung pengalokasian berfungsi untuk menambah data hitung. Form hitung alokasi terdiri dari nama barang, jumlah alokasi, tujuan, jumlah kebutuhan harian, dan jumlah stok. Tombol icon plus berfungsi untuk menambah variabel perhitungan yaitu tujuan, jumlah kebutuhan harian, dan jumlah stok. Tombol create berfungsi sebagai submit button untuk menyimpan data ke database. Gambar halaman input data hitung pengalokasian seperti pada Gambar 3. 9 Halaman input data hitung pengalokasian. 


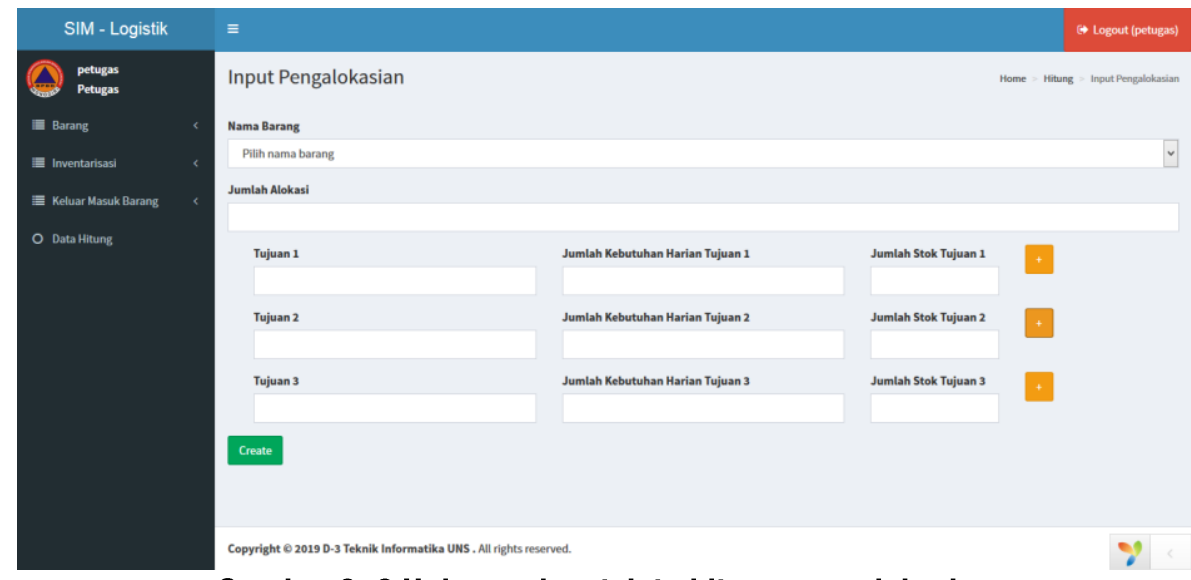

Gambar 3. 9 Halaman input data hitung pengalokasian

\subsection{Pengujian}

Pengujian pada sistem dilakukan menggunakan pengujian black box. Pengujian black box berfungsi untuk menguji fungsionalitas sistem berhasil dijalankan atau tidak. Tabel pengujian black box sistem seperti ditunjukkan pada Tabel 3. 2 Pengujian Black Box.

Tabel 3. 2 Pengujian Black Box

\begin{tabular}{|c|c|c|c|}
\hline No & $\begin{array}{l}\text { Kasus yang } \\
\text { diuji }\end{array}$ & Hasil yang diharapkan & Hasil pengujian \\
\hline 1 & $\begin{array}{l}\text { Mengelola data } \\
\text { kategori }\end{array}$ & $\begin{array}{l}\text { Menambah data kategori, melakukan pencarian data kategori, } \\
\text { mengedit data kategori, menampilkan detail view data kategori, } \\
\text { menghapus data kategori }\end{array}$ & Berhasil \\
\hline 2 & $\begin{array}{l}\text { Mengelola data } \\
\text { sumber }\end{array}$ & $\begin{array}{l}\text { Menambah data sumber, melakukan pencarian data sumber, } \\
\text { mengedit data sumber, menampilkan detail view data sumber, } \\
\text { menghapus data sumber }\end{array}$ & Berhasil \\
\hline 3 & $\begin{array}{l}\text { Mengelola data } \\
\text { kecamatan }\end{array}$ & $\begin{array}{l}\text { Menambah data kecamatan, melakukan pencarian data } \\
\text { kecamatan, mengedit data kecamatan, menampilkan detail view } \\
\text { data kecamatan, menghapus data kecamatan }\end{array}$ & Berhasil \\
\hline 4 & $\begin{array}{l}\text { Mengelola data } \\
\text { kelurahan }\end{array}$ & $\begin{array}{l}\text { Menambah data kelurahan, melakukan pencarian data kelurahan, } \\
\text { mengedit data kelurahan, menampilkan detail view data } \\
\text { kelurahan, menghapus data kelurahan }\end{array}$ & Berhasil \\
\hline 5 & $\begin{array}{l}\text { Mengelola data } \\
\text { bencana }\end{array}$ & $\begin{array}{l}\text { Menambah data bencana, melakukan pencarian data bencana, } \\
\text { mengedit data bencana, menampilkan detail view data bencana, } \\
\text { menghapus data bencana }\end{array}$ & Berhasil \\
\hline 6 & $\begin{array}{l}\text { Mengelola data } \\
\text { barang }\end{array}$ & $\begin{array}{l}\text { Menambah data barang, melakukan pencarian data barang, } \\
\text { mengedit data barang, menampilkan detail view data barang, } \\
\text { menghapus data barang, mencetak kartu barang }\end{array}$ & Berhasil \\
\hline 7 & $\begin{array}{l}\text { Mengelola data } \\
\text { inventarisasi }\end{array}$ & $\begin{array}{l}\text { Menambah data inventarisasi, melakukan pencarian data } \\
\text { inventarisasi, mengedit data inventarisasi, menampilkan detail } \\
\text { view data inventarisasi, menghapus data inventarisasi, mencetak } \\
\text { rekap berdasarkan jenis, mencetak rekap berdasarkan kategori }\end{array}$ & Berhasil \\
\hline 8 & $\begin{array}{l}\text { Mengelola data } \\
\text { kedaluwarsa }\end{array}$ & $\begin{array}{l}\text { Menambah data kedaluwarsa, melakukan pencarian data } \\
\text { kedaluwarsa, mengedit data kedaluwarsa, menampilkan detail } \\
\text { view data kedaluwarsa, menghapus data kedaluwarsa, } \\
\text { meampilkan flash message barang kedaluwarsa }\end{array}$ & Berhasil \\
\hline 9 & $\begin{array}{l}\text { Mengelola data } \\
\text { penyimpanan }\end{array}$ & $\begin{array}{l}\text { Menambah data penyimpanan, melakukan pencarian data } \\
\text { penyimpanan, mengedit data penyimpanan, menampilkan detail } \\
\text { view data penyimpanan, menghapus data penyimpanan, } \\
\text { mencetak bukti penyimpanan, mencetak rekap penyimpanan }\end{array}$ & Berhasil \\
\hline
\end{tabular}




\begin{tabular}{|c|c|c|c|}
\hline & & $\begin{array}{l}\text { berdasarkan durasi, mencetak rekap penyimpanan berdasarkan } \\
\text { sumber }\end{array}$ & \\
\hline 10 & $\begin{array}{l}\text { Mengelola data } \\
\text { detail masuk }\end{array}$ & $\begin{array}{l}\text { Menambah data detail masuk, melakukan pencarian data detail } \\
\text { masuk, mengedit jumlah detail masuk, menampilkan detail view } \\
\text { data detail masuk, menghapus data detail masuk }\end{array}$ & Berhasil \\
\hline 11 & $\begin{array}{l}\text { Mengelola data } \\
\text { tidak layak }\end{array}$ & $\begin{array}{l}\text { Menambah data tidak layak, melakukan pencarian data tidak } \\
\text { layak, mengedit data tidak layak, menampilkan detail view data } \\
\text { tidak layak, menghapus data tidak layak, mencetak rekap } \\
\text { berdasarkan kondisi, memvalidasi tindak lanjut }\end{array}$ & Berhasil \\
\hline 12 & $\begin{array}{l}\text { Mengelola data } \\
\text { hitung }\end{array}$ & $\begin{array}{l}\text { Menambah data hitung, melakukan pencarian data hitung, } \\
\text { mengedit data hitung, menampilkan detail view data hitung, } \\
\text { menghapus data hitung, mencetak hitung pengalokasian }\end{array}$ & Berhasil \\
\hline 13 & $\begin{array}{l}\text { Mengelola data } \\
\text { posko }\end{array}$ & $\begin{array}{l}\text { Menambah data posko, melakukan pencarian data posko, } \\
\text { mengedit data posko, menampilkan detail view data posko, } \\
\text { menghapus data posko }\end{array}$ & Berhasil \\
\hline 14 & $\begin{array}{l}\text { Mengelola data } \\
\text { pengeluaran }\end{array}$ & $\begin{array}{l}\text { Menambah data pengeluaran, melakukan pencarian data } \\
\text { pengeluaran, mengedit data pengeluaran, menampilkan detail } \\
\text { view data pengeluaran, menghapus data pengeluaran, mencetak } \\
\text { bukti pengeluaran, mencetak cetak rekap pengeluaran } \\
\text { berdasarkan durasi, mencetak cetak rekap pengeluaran } \\
\text { berdasarkan kondisi, mencetak cetak rekap pengeluaran } \\
\text { berdasarkan posko / tujuan, mencetak cetak rekap pengeluaran } \\
\text { berdasarkan bencana, memvalidasi pengiriman }\end{array}$ & Berhasil \\
\hline 15 & $\begin{array}{l}\text { Mengelola data } \\
\text { detail keluar }\end{array}$ & $\begin{array}{l}\text { Menambah data detail keluar, melakukan pencarian data detail } \\
\text { keluar, mengedit jumlah detail keluar, menampilkan detail view } \\
\text { data detail keluar, menghapus data detail keluar }\end{array}$ & Berhasil \\
\hline 16 & $\begin{array}{l}\text { Mengelola data } \\
\text { peminjaman }\end{array}$ & $\begin{array}{l}\text { Melakukan pencarian data peminjaman, mencetak rekap } \\
\text { peminjaman berdasarkan durasi, mencetak rekap peminjaman } \\
\text { berdasarkan posko / tujuan, mencetak rekap peminjaman } \\
\text { berdasarkan pengembalian, memvalidasi pengembalian }\end{array}$ & Berhasil \\
\hline
\end{tabular}

\section{KESIMPULAN}

Berdasarkan pembahasan di atas, kesimpulan yang dapat diambil adalah telah dibuat sistem informasi manajemen logistik dan peralatan. Berdasarkan hasil pengujian pada sistem, sistem dapat menjalankan fungsionalitasnya. Fungsionalitas tersebut antara lain mengelola data kategori, data sumber, data kecamatan, data kelurahan, data bencana, data barang, data inventarisasi, data kedaluwarsa, data penyimpanan, data detail masuk, data tidak layak, data posko, data hitung, data pengeluaran, data detail keluar, dan data peminjaman.

\section{DAFTAR PUSTAKA}

[1] Y. Agustiningsih, "Sistem Informasi Warehouse Bantuan Logistik Korban Bencana Alam Berbasis Web dengan Framework Codeigniter 3.0 (Studi Kasus: Gunung Merapi)", Universitas Sebelas Maret, 2016.

[2] D. Karlina and S. Wicaksono, "Sistem Informasi E-Logistik pada Siklus Proses Order Bahan Baku", Jurnal Buana Informatika, vol. 5, no. 2, pp. 95 - 104, 2014

[3] R. Hidayat, "Rancang Bangun Sistem Informasi Logistik", Jurnal Optimasi Sistem Industri, vol. 13, no. 2, pp. 707 $-724,2014$

[4] M. Meyliawati and E. Suprianto, "Tinjauan Sistem Prosedur Pengeluaran Material C212 di Gudang Manajemen Persediaan PT. X”, INDEPT, vol. 6, no. 1, pp. 17 - 23, 2016

[5] Triwibowo, R. Kridalukmana and K. Martono, "Pembuatan Aplikasi Terintegrasi, Pendataan Barang di Gudang Berbasis Android", Jurnal Teknologi dan Sistem Komputer, vol. 3, no. 2, pp. 320 - 334, 2015

[6] D. Rinawati, D. Sari, F. Priatamphatie and Fahrudin, "Rancang Bangun Sistem Informasi Bantuan Logistik Bencana Studi Kasus pada BPBD Kabupaten Magelang”, J@ti Undip: Jurnal Teknik Industri, vol. 13, no. 1, pp. $51-60,2018$

[7] D. J Bowersox, D. J Closs, M. Cooper and J. C Bowersox, Supply Chain Logistics Management, 4th ed. Singapore: McGraw-Hill, 2013 